\title{
HARMONISASI, INTEGRASI DESA PAKRAMAN DENGAN DESA DINAS YANG MULTI ETNIK DAN MULTIAGAMA MENGHADAPI PERGESERAN, PELESTARIAN, DAN KONFLIK DI BALI
}

\author{
Dewa Bagus Sanjaya ${ }^{1}$, Wayan Sugiartha ${ }^{2}$ \\ ${ }^{1} J u r u s a n$ Pendidikan Pancasila dan Kewarganegaraan, 2 Jurusan Pendidikan Sejarah \\ Universitas Pendidikan Ganesha \\ Singaraja, Indonesia
}

\begin{abstract}
Abstrak
Penelitian etnografi ini bertujuan untuk menganalisis hubungan desa dinas dan desa pakraman, dan integrasi masyarakat di Provinsi Bali. Penelitian ini melibatkan prajuru desa pakraman, masyarakat Hindu, dan masyarakat non-Hindu. Penentuan subjek penelitian dengan menggunakan teknik puposive. Data dikumpulkan dengan wawancara, observasi dan pencatatan dokumen. Data dianalisis secara kualitatif. Hasil penelitian menunjukkan bahwa desa pakraman dan desa dinas berada dalam kondisi harmonis, sehingga memunculkan ungkapan "satu badan dua kepala", sekaligus sebagai wujud integrasi masyarakat. Desa pakraman melaksanakan tugas di bidang agama, adat, dan budaya,sedangkan desa dinas di bidang administrasi.
\end{abstract}

Kata-kata kunci: desa pakaraman, desa dinas, harmonisasi.

\begin{abstract}
Ethnographic research aims to analyze the relationship between the village and Pakraman official, and community integration in the province of Bali. The study involved prajuru Pakraman, Hindus, and non-Hindu communities. Determination of research subjects by using puposive. Data were collected through interviews, observation and recording of documents. Data were analyzed qualitatively. The results showed that Pakraman and village offices were in a state of harmony, giving rise to the phrase "one body two heads", as well as a form of community integration. Pakraman carry out tasks in the field of religion, customs, and culture, while the village official in the administration.
\end{abstract}

Key words: pakraman village, village office, harmonization

\section{PENDAHULUAN}

Desa pakraman sebagai salah satu komponen dalam struktur kemasyarakatan Bali tidak hanya dihuni etnik Bali, melainkan banyak pula etnik lain, sehingga melahirkan desa adat multietnik dan multi agama. Di Bali selain desa pakraman juga terdapat desa dinas. Pelaksanaan pemerintahan desa di Bali diibaratkan sebagai ular berkepala dua. Kedua desa tersebut mempunyai kedudukan, tugas dan fungsi yang berbeda. Dilihat dari sejarah hidup dan kehidupan bahwa desa dinas memang lebih beruntung bila dibandingkan desa pakraman karena desa dinas mendapat fasiltas dari pemerintah/negara, walaupun sebenarnya dia lahir lebih muda.

Kehadiran etnik non-Bali dan agama non-Hindu pada desa pakraman mengakibatkan struktur sosial desa pakraman terpilah menjadi dua yakni, warga muwed (asli) dan tamiu (pendatang). Warga muwed acapkali dianggap berkedudukan lebih tinggi daripada warga tamiu. Hal ini tidak semata-mata bertalian dengan posisi sosial, melainkan berkaitan pula dengan peran kemasyarakatan yang di dalamnya menyangkut siapa yang memiliki akses, dan siapa yang memiliki wewenang untuk membuat keputusan, (Atmadja, 2004). Arogansi desa pakraman membuat sekat 
yang tajam antara warga desa pakraman dan desa dinas yang multietnis dan multiagama, sehingga dapat mengganggu keharmonisan dan integrasi desa pakraman dan desa dinas, warga desa pakraman dengan warga etnis dan agama non-Hindu (Atmadja, 2004). Desa pakraman sesungguhnya sejak awal telah ditata untuk menjadi desa religius. Hal ini dapat dibuktikan dari realitas historis yaitu desa pakraman dibentuk berlandaskan konsepkonsep dan nilai-nilai filosofis agama Hindu. Desa pakraman mengacu kepada kelompok tradisional dengan dasar ikatan adatistiadat, dan terikat oleh adanya tiga pura utama yang disebut kahyangan Tiga atau pura lain yang berfungsi seperti itu, yang disebut kahyangan desa. Dalam melaksanakan tugas dan kewenangan, desa pakraman berpedoman pada awig-awig. Awig-awig" merupakan pedoman dasar dari desa pakraman dalam pemerintahannya. Desa pakraman di Bali, sebagaimana juga komunitas-komunitas kecil lainnya, secara hipotetis-teoritis dapat dikatakan lahir karena tuntutan kodrati manusia sebagai makhluk sosial, yang tidak mampu memenuhi berbagai kebutuhannya secara individual, sehingga mereka sepakat untuk hidup bersama-sama dalam suatu ikatan tertentu, guna mempermudah pencapaian tujuan atau pemenuhan berbagai kebutuhannya (Griadhi, 1991).

Masalah yang diangkat dalam penelitin ini adalah (1) Baimanakah hubungan desa dinas dan desa pakraman yang multietnis dan agama di daerah pariwisata Provinsi Bali? (2) Bagaimanakah tugas dan kewenangan desa dinas yang multietnis dan multiagama sesuai dengan Undang-Undang No. 32 Tahun 2004 tentang pemerintahan daerah? (3) Bagaimanakah pergeseran dan pelestarian tugas dan kewenangan desa pakraman yang multietnis dan multiagama? (4) Bagaimanakah dinamika komunikasi warga desa adat dengan warga di luar desa pakraman (nonHindu)? (5) Bagaimanakah pola integrasi masyarakat sebagai dampak dari pergeseran, pelestarian pelaksanaan tugas dan kewenanngan desa pakraman yang multietnis dan multiagama?

\section{METODE}

Penelitian ini menggunakan rancangan penelitian kualitatif yang bersifat naturalistik dan etnografis, sehingga penekanannya bukan pada pengukuran, melainkan pada upaya mendeskripsikan dan menjelaskan secara aktual, faktual, alamiah, holistik dan emik tentang eksistensi, harmonisasi desa pakraman dengan desa dinas. Objek penelitian ini adalah terkait dengan tugas dan kewenangan desa pakraman dan desa dinas. Data yang diperlukan adalah data deskriptif, dengan cara wawancara mendalam, observasi, dan pencatatan dokumen. Informasi dalam penelitian ini dipilih secara purpossive. Subjek penelitian ini adalah orang. Subjek penelitian ini merupakan informan kunci dan informan lain serta sebagai partisipan yang diperlukan untuk pengumpulan data (Carspecken, 1994). Subjek penelitian meliputi: (a) prajuru desa pakraman, (b) kepala desa, (c) masyarakat dari berbagai etnis. Penelitian ini menggunakan teknik analisis data secara kualitatif dengan berbagai kegiatan (1) reduksi data, (2) display data, (3) interpretasi data, (4) verifikasi data, (5) penarikan simpulan (Miles dan Huberman, 1992). Sebagai penelitian etnografi, penelitian ini mengkaji tentang keberadaan, harmonisasi dan integrasi desa pakraman dan desa dinas sebagai nilai budaya. Desa pakraman sebagai nilai budaya dengan perangkat prajuru (pengurus), awig-awig (sistem teknologi), sistem kekerabatan dan susunan masyarakatnya (sistem sosial), dan ideologi tri hita karana serta nilainya sebagai sistem nilai budaya dapat diintervensi oleh desa dinas. Selanjutnya, bagaimana desa pakraman sebagai nilai budaya dalam mempertahankan eksistensinya dan otonominya sebagai desa yang otonom. 
HASIL

Di Bali ada dua jenis desa, yaitu: desa pakraman dan desa dinas. Desa pakraman sebagai desa dresta adalah kesatuan masyarakat hukum adat propvinsi Bali yang mempunyai satu kesatuan tradisi dan tata krama pergaulan hidup masyarakat umat Hindu secara turun temurun dalam ikatan kahyangan tiga. Dilihat dari sejarah hidup desa dinas dan desa pakraman, bahwa desa pakraman lebih tua bila dibandingkan dengan desa dinas, tetapi desa dinas lebih beruntung. Keberuntungan itu tampak dalam pemberian fasilitas oleh pemerintah berupa fasilitas kantor, kelengkapan adminsitrasi dan aparat desa. Agar kedua desa di atas dapat hidup berdampingan perlu adanya pemahaman tugas, tanggung jawab dan komitmen masing-masing. Desa dinas dan desa pakraman di Bali berada dalam kondisi harmonis dan terjadi hubungan komunikasi antara unsur desa dinas dan desa pakraman dalam susunan struktur pemerintahan. Keharmonisan desa dinas dan desa pakraman memunculkan ungkapan "satu badan dua kepala". Keharmonisan hubungan antara desa dinas dan desa pakraman menurut Pitana (1994) karena ada kemungkinan antara lain: (1) satu desa dinas mempunyai luas wilayah dan penduduk yang sama dengan satu desa pakraman, (2) satu desa dinas meliputi beberapa desa pakraman, (3) satu desa pakraman, terdiri beberapa desa dinas, (4) satu desa dinas meliputi beberapa desa pakraman dan sebagian dari desa pakraman lain. Secara normatif, dalam desa dinas dan desa pakraman, terdapat hubungan yang harmonis, tetapi kenyataannya terjadi hubungan yang suboordinat. Desa pakraman sering dianggap sebagai bagian atau bawahan daripada desa dinas. Ironisnya, berbagai program dan kebijakan pembangunan yang dilakukan di tingkat desa pakraman belum melibatkan desa pakraman sebagaimana mestinya. Program-program pemerintah umumnya dilakukan melalui saluran kedinasan yaitu melalui desa dinas atau kelurahan. Padahal, sampai saat ini, desa pakraman diakui merupakan benteng yang sangat tangguh untuk membendung berbagai dampak negatif dari luar. Atas dasar ini, perlu kiranya dilakukan usahausaha untuk mengurangi intervensi desa dinas terhadap urusan desa pakraman.

Pasal 5 Perda No. 3 Tahun 2001 tentang desa pakraman dinyatakan bahwa desa pakraman mempunyai beberapa tugas yaitu: (a) membuat awig-awig,(b) mengatur krama desa, (c) mengatur pengelolaan harta kekayaan desa, (d) bersama-sama pemerintah melaksanakan pembangunan di segala bidang terutama bidang keagamaan, kebudayaan, dan kemasyarakatan; (e) membina dan mengembangkan nilai-nilai budaya Bali dalam rangka memperkaya, melestarikan, dan mengembangkan kebudayaan nasional pada umumnya dan kebudayaan daerah pada khususnya, berdasarkan paras-paros, sagilik-saguluk, salunglung-sabayantaka (musyawarah mufakat), (f) mengayomi krama desa. Wewenang desa pakraman adalah sebagai berikut: (a) menyelesaikan sengketa adat dan agama dalam lingkungan wilayahnya dengan tetap membina kerukunan dan toleransi antarkrama desa sesuai dengan awig-awig dan adat kebiasaan setempat; (b) turut serta menetukan setiap keputusan dalam pelaksanaan pembangunan yang ada di wilayahnya terutama yang berkaitan dengan tri hita karana; (c) melaksanakan perbuatan hukum di dalam dan di luar desa adat.

Awig-awig memegang peranan sangat penting dalam mengatur tata kehidupan masyarakat Bali, baik di bidang agama/kebudayaan maupun dalam bidang sosial ekonomi. Masyarakat Bali sampai saat ini masih menjunjung tinggi dan menghormati awig-awig desa pakraman dan menaati serta mematuhi ketentuanketentuanya sehingga awig-awig desa pakraman dalam pembinaan hukum nasional harus diperhitungkan. Awig-awig pada umumnya tidak tertulis, sedangkan 
yang ditulis pada zaman dahulu disebut pengeling-eling atau tunggul (catatan). Dalam Peraturan Daerah No. 3 Tahun 2001 pasal 1 huruf (11), awig-awig adalah aturan yang dibuat oleh krama dan atau krama banjar pakraman yang dipakai sebagai pedoman dalam pelaksanaan tri hita karana sesuai dengan desa mawacara dan dharma agama di desa pakraman masing.masing. Lebih lanjut ditegaskan dalam perda tersebut yaitu pasal 7 ayat (1) bahwa setiap desa pakraman agar memiliki awig-awig yang tertulis; pasal 7 ayat (2) awig-awig desa pakraman tidak boleh bertentangan dengan dengan Pancasila, Undang-undang Dasar 1945, dan peraturan perundangundangan yang berlaku. Semangat untuk menuliskan awig-awig desa pakraman bermula tahun 1969, ketika berlangsungnya "Seminar Hukum I tentang "Pembinaan Awig-awig Desa dalam Tertib Masyarakat" . Rangkuman hasil seminar sebagaimana ditulis oleh Windia (2008) yaitu setiap awigawig desa pakraman dibuat dalam bentuk tertulis. Dalam waktu singkat supaya diusahakan penulisannya, dengan catatan, sambil menunggu proses penulisan tersebut, awig-awig yang tidak tertulis masih tetap mempunyai kekuatan dan berlaku sebagaimana biasa. Di dalam penulisan awig-awig oleh desa, supaya diperhatikan sistematika yang menjamin adanya suatu susunan yang mudah dipahami dan dipergunakan.

Temuan di lapangan, bahwa semua desa pakraman yang berada di lokasi pariwisata di Bali yang menjadi tempat penelitian telah memiliki awig-awig. Ini berarti bahwa masyarakat yang berada di daerah pariwisata menyadari pentingnya aturan yang dapat mengatur kehidupan masyarakat terutama terkait dengan adat, budaya dan agama. Di samping itu, masyarakat telah menyadari pentingnya ketaatan masyarakat terhadap peraturan yang telah menjadi landasan dalam penyusunan awig-awig, yaitu tentang desa pakraman. Tugas lain desa pakraman adalah mengatur krama. Desa pakraman yang berada di daerah pariwisata di Bali telah mengatur tentang keberadaan krama (warga) dalam awig-awig desa pakraman. Bahkan untuk menjabarkan tugas dan kewajiban krama secara lebih rinci, desa pakraman telah membuat perarem (kesepakatan) untuk mengatur krama muwed dan krama tamiu. Desa pakraman membina penduduk pendatang dalam kaitannya dengan tri hita karana sebagai kearifan lokal di Bali yang tertuang dalam pasal 13, Peraturan Daerah Bali No 3 Tahun 2001 tetang desa pakraman yang berbunyi "Desa adat dapat berpartisipasi aktif dalam upaya pembinaan terhadap penduduk pendatang dalam kaitannya dengan tri hita karana sehingga terwujud hubungan yang harmonis. Pasal 3 ayat (2) Perda No. 3 Tahun 2001 dalam hal ini yang menjadi krama desa adalah orang yang menjadi anggota desa menurut tata cara dan syarat yang diatur dalam awig-awig desa. Untuk menjadi krama desa tidak hanya berdasarkan atas dasar domisili, tetapi juga dianut stelsel aktif, yakni adanya permohonan/permintaan dari seseorang (yang sudah berkeluarga) untuk menjadi krama desa. Dengan demikian, bisa saja terjadi bahwa krama tersebut berada di luar wilayah desa yang bersangkutan dan sebaliknya. Ketentuan otonomi desa adat semestinya bergerak sesuai dengan desa mawacara dan desa, kala, patra dengan semangat Negara Kesatuan Republik Indonesia (NKRI). Sebagai desa pariwisata di Bali yang mempunyai sejarah dan realitas dengan penduduk pendatang, hubungan konstruktif yang berkaitan dengan kerukunan, dan multikultur dalam upacara, agama, dan perkawinan dan lain-lain tidak terhindarkan. Dampak sosial politik terkait dengan otonomi desa adat, bahwa desa adat memiliki otonomi asli "bukan pemberian negara" dalam pengertian bahwa ada hak dan otoritas dalam mengatur diri sendiri tanpa campur tangan negara di dalamnya, sesuai dengan desa mawacara, dan kesepakatan-kesepakatan.

Terkait dengan pengelolaan harta 
kekayaan desa pakraman, dalam pasal 9 Peraturan Daerah No. 03 Tahun 2001 tentang Desa Pakraman, telah diatur tentang harta kekayaan desa. Harta kekayaan desa pakraman adalah kekayaan yang telah ada maupun yang akan ada yang berupa harta bergerak dan tidak bergerak, material dan inmaterial serta benda-benda yang bersifat religius magis yang menjadi milik desa. Pengelolaan harta kekayaan desa pakraman dilakukan oleh prajuru desa sesuai dengan awig-awig desa pakraman masing-masing. Setiap pengalihan/perubahan status harta kekayaan desa pakraman harus mendapat persetujuan paruman. Pengawasan harta kekayaan desa pakraman dilakukan oleh krama desa pakraman. Tanah desa pakraman dan tanah milik desa pakraman bebas dari pajak bumi dan bangunan. Dalam hubungan dengan pengelolaan harta kekayaan desa, ada desa pakraman yang mengalami pergeseran, seperti Desa Pakraman Medewi. Menurut Gusti Kade Wenia (prajuru Desa Pakraman Medewi) bahwa tanah milik Desa Pakraman Medewi dikelola oleh pribadi dan untuk kepentingan pribadi. Namun, seiring perjalanan waktu, kurang lebih 15 (lima belas) tahun terakhir tanah milik desa pakraman dikelola oleh desa pakraman untuk kepentingan desa pakraman seperti piodalan, perbaikan pura dan lain-lain. Desa pakraman sebagai desa otonom mempunyai kewenangan untuk mengurus dan menyelenggarakan kehidupan rumah tangganya sendiri yang bersifat sosial religius, sosial ekonomi, dan sosial kemasyarakatan. Desa pakraman mempunyai tiga macam kekuasaan yakni: (a) kekuasaan untuk menetapkan aturan, (b) kekuasaan untuk menyelenggarakan kehidupan organisasi yang bersifat sosial religius, (c) kekuasaan untuk menyelesaiakan sengketa-sengketa (Widnyana dalam Astara, 2010).

$$
\text { Pelaksanaan tugas dan }
$$

kewenangan desa pakraman di Bali, telah mengalami dinamika. Hal tersebut tampak dari adanya konflik yang bernuansa "adat".
Berita yang mengejutkan yakni pembakaran rumah di Tusan, Klungkung oleh sekelompok orang. Konflik ini akar musababnya adalah persoalan "adat". Sebenarnya, konflik merupakan sebuah fenomena yang serba hadir dalam kehidupan manusia. Patut disadari dan dimengerti, konflik itu tidak otomatis bersifat manifest. Bisa juga laten dan kemudian bisa hilang ketika pihak-pihak yang merasa berkonflik mampu menemukan titik temu di antara mereka tanpa harus menuangkannya dalam bentuk kekerasan. Kini, entah mengapa, kesantunan itu berubah menjadi beringas, gelap mata serta anarkis. Menurut bahwa latar belakang terjadinya kasepekang terhadap warga di Desa Pakraman Tusan adalah masalah "adat". Kasus kesepekang kembali terjadi, kali ini menimpa seorang warga Kedungu Tabanan, yang disebabkan oleh perlakuan menodai tempat suci. Luar biasa, masyarakat Bali yang berlandaskan ajaran agama Hindu menerapkan suatu sanksi yang kejam dan tidak manusiawi. Sanksi kesepekang menjadi noda hitam dari peradaban masyarakat Hindu Bali. Terlalu banyak orang yang gembar-gembor mengenai betapa halus dan fleksibelnya masyarakat Bali yang setiap gerak langkahnya berdasarkan agama Hindu yang lembut. Sangat ironis padasaat kita semua mulai terbiasa berdiskusi mengenai masalah memanusiakan manusia, kita masih berkutat dengan adanya sanksisanksi aneh dan kejam.

$$
\text { Terkait dengan integrasi }
$$

masyarakat, multikulturalisme secara normatif telah tertuang dalam Peraturan Daerah No. 3 Tahun 2012 tentang Desa Pakraman dalam pasal 3 ayat (7): parahyangan dan tempat suci, baik bagi umat Hindu maupun umat lain yang ada dalam wilayah desa pakraman/banjar pakraman dijaga bersama-sama oleh seluruh warga/krama dari desa pakraman/banjar pakraman atas dasar toleransi dan kerukunan serta saling menghormati dalam rangka membina rasa 
persatuan dan kesatuan masyarakat Indonesia. Implementasi dari pasal 3 aya7 di atas terdapat hubungan secara sosiohistoris dari aspek multikulturalisme sudah mulai ketika mads langa di Kuta yaitu ketika zaman kerajaan. Mads langa kawin dengan keturunan Tionghoa sehingga disebut mads langa adalah bagian dari kehidupan dan dinamika masyarakat Tionghoa di Desa Pakraman Kuta. Pada mulanya tradisi Tionghoa di Desa Pakraman Kuta, lakilakinya yang kawin dengan orang Bali (Hindu) di Desa Pakraman Kuta, akan membuat "sanggah/merajan" seperti orang Hindu Bali lainnya. Penanganan terhadap warga Hindu dan non-Hindu yang arogan akan dapat mengganggu kesatuan/integrasi masyarakat, sebaliknya kalau terlalu lemah akan berdampak terhadap eksistensi desa pakraman itu sendiri. Untuk itu mencari jalan tengah yang bijaksana yaitu dengan memberikan kesempatan yang lebih besar kepada warga masyarakat memikirkan desanya sendiri untuk kemajuan desa, dan akomodatif terhadap warga tamiu untuk menghindari hal-hal yang tidak diinginkan bersama. Upaya seperti itu tidaklah berlebihan karena kognisi orang Bali pada umumnya bertumpu pada rwa bhineda di satu sisi memberikan landasan bagi mereka untuk menerima perbedaan sebagai sesuatu keharusan. Namun, di sisi lain, hal itu bisa melahirkan pemikiran yang dualisme dikotomik. Misalnya, dalam melihat hubungan antara warga muwed dan tamiu, mereka tidak selamanya menempatkan dalam hubungan yang saling melengkapi, malainkan sebagai dua unsur yang berlawanan. Seperti dikemukakan oleh Fay dalam Atmadja (2004) dualisme dikotomik bisa mendorong terjadinya suatu pertentangan antara dua entitas dan kekuatan yang harus dipilih keberpihakannya, yakni pihak ini atau pihak itu. Bersamaan dengan itu, konflik yang semula bersifat perebutan sumber daya ekonomi maupun politik bisa berubah menjadi konflik antara kita dan mereka, muwed dan tamiu, atau Bali melawan etnik
non-Bali. Upaya-upaya tersebut di atas relevan dengan pendapat Soerjono (2004) yang menyatakan bahwa ada tiga jenis pola penanganan kasus adat, yaitu : pola negosiasi, pola mediasi, dan pola ajudikasi. Negosiasi yakni perundingan di antara pihak-pihak yang berselisih dengan menggunakan cara-cara yang mereka anggap baik. Mediasi, yaitu kepala adat bertindak sebagai mediator atau penengah bagi pihak-pihak yang bersengketa, sedangkan ajudikasi, kepala adat bertindak sebagai hakim yang akan memberikan keputusan tarhadap perkara yang diajukan Masyarakat multietnik selalu terlibat dalam proses sosial berbentuk integrasi dan atau konflik. Namun, sering konflik dianggap sebagai patologi sosial, padahal jika dikelola dengan baik bisa menjadi kekuatan pembangunan bangsa (Miall dalam Pageh, 2004). Secara teoretik, ada beberapa penyebab integrasi yang perlu dikelola agar dapat menjadi kekuatan, di antaranya kesepakatan sistem budaya fundamental koordinatif, tidak dapat dipungkiri Pancasila merupakan to be or not to be; adanya kebudayaan dominan; kuantitas sosiodemografis. Dibutuhkan adanya kelompok sosial menyilang dan memotong, seperti klub Sepak Bola, Volley misalnya; dan penciptaan budaya komplementer yang saling melengkapi. Beberapa fakta sosial itu perlu diupayakan secara bersama-sama dan terus-menerus agar kerukunan sosial antarsegmen bangsa itu terjadi (Atmadja, 2001), sedangkan integrasi multikultural dapat berbentuk akomodatif, kooperatif, toleran, koordinatif, peminjaman unsur budaya selektif, dengan penuh kesadaran agar terjadi integrasi sosial secara damai.

Namun, jika dicermati warga desa pakraman tidak lagi hanya etnik Bali, melainkan banyak pula etnik lain, sehingga melahirkan desa pakraman multietnik. Pada tahun 2000, dari 162 desa pakraman di Kabupaten Buleleng, ada sebanyak 72 $(45,06 \%)$ desa pakraman bercorak multietnik-berpenduduk campuran antara etnik Bali, Jawa, Madura, Bugis, Sasak, 
Tionghoa, dan lain-lain, sedangkan sisanya yakni sebanyak 90 (54,94\%) desa pakraman bercorak monoetnik - berpenduduk hanya etnik Bali (Tim Ahli Bupati Buleleng dalam Atmadja, 2004). Setiap etnik mengembangkan identitas budaya sendirisendiri, misalnya dalam bentuk bahasa, kesenian, adat-istiadat, dan lain-lain. Mereka menganut pula agama yang berbeda-beda, yakni Hindu, Katolik, Kristen, Buddha, karena itu mereka tidak saja bercorak multietnik, tetapi juga multiagama. Apapun agama yang mereka anut, selalu menekankan pada kedamaian lewat pengembangan persaudaraan yang universal. Hal ini dapat ditunjukkan dari kata-kata yang sering mereka ucapkan pada setiap pertemuan di ruang publik, misalnya agama Hindu mengenal kata Shanti, agama Buddha mengenal kata Sadhu, Kristen mengenal kata Shlama, dan Islam mengenal kata Salam. Semua ungkapan tersebut bermakna damai (Penerbit Qalam, 2002, Kung, 2000 dalam Atmadja, 2004). Begitu pula kearifan lokal yang mereka miliki, sebagaimana yang berlaku pada kebudayaan Bali, juga mendambakan kedamaian lewat pengembangan solidaritas sosial atau menyama braya. Keberagaman merupakan suatu keharusan bagi kelangsungan hidup manusia. Kenyataan mengharuskan kita bersikap arif untuk menerima keberagaman, sesuai dengan asas Bhineka Tunggal lka. Penerimaan terhadap asas Bhineka Tunggal lka harus mengacu kepada multikulturalisme, yakni ideologi yang menekankan pada pemahaman, penghargaan, penghormatan, dan pengagungan terhadap perbedaan dalam kesederajatan, baik secara individu maupun kebudayaan (Suparlan, 2002). Multikulturalisme harus dipraktekkan dalam kehidupan masyarakat. Untuk itu, setiap orang sebaiknya tidak berpetualang dengan konflik menggunakan isu perbedaan yang ada, baik atas dasar agama maupun kesukubangsaan. Sebaliknya, setiap orang harus membiasakan diri untuk saling menghormati atas perbedaan yang kita miliki, mengembangkan dialog secara terus menerus guna mewujudkan toleran terhadap perbedaan. Sejalan pandangan di atas, Alhumani (1999) menawarkan beberapa model perekat sosial yang bersifat integratif di Tasikmalaya, yaitu (1) doktrin agama Islam, (2) kepemimpinan Kyai yang menjadi figur sentral dalam masyarakat, (3) hubungan kekerabatan, (4) kebudayaan lokal. Konflik juga sebuah ekspresi heterogenitas kepentingan, nilai, dan keyakinan yang muncul sebagai formasi baru yang ditimbulkan oleh perubahan sosial yang muncul bertentangan dengan hambatan yang diwariskan. Seiring dengan pesatnya perubahan karena kemajuan pariwisata pada masyarakat Bali yang secara realitas adalah masyarakat majemuk, sarat dengan konflik, baik konflik adat, maupun konflik sosial. Usaha-usaha dari prajuru desa pakraman dan prajuru banjar pakraman sangat relevan dengan kearifan lokal yang dimiliki oleh masyarakat Bali, yaitu mendambakan kedamaian lewat solidaritas sosial atau menyama braya. Pandangan Pancasila yang menekankan pada toleransi sebagai modal sosial terbentuknya masyarakat Indonesia yang damai berlandaskan Bhineka Tunggal Ika. Pitana (2001) menyatakan bahwa potensi konflik di Bali sudah ada yang manifes antara lain: (1) potensi konflik antaretnis, khususnya etnis Bali dengan non-Bali. Potensi ini semakin membesar dengan munculnya kristaliasi etnis diantara manusia Bali yang semakin membuat tembok pembatas antara kekitaan dengan kemerdekaan; (2) potensi konflik antar kelas yang berlatar belakang ekonomi. Masyarakat kelas ekonomi bawah merasa termarinalisasi sudah mulai memposisikan diri secara frontal dengan kaum kaya, khususnya pengusaha; (3) kelompok homoaegualis dan homo-hierarchius; (4) potensi konflik yang merupakan penyakit menaun yaitu antara masyarakat Bali yang demokratis dengan masyarakat Bali yang mempertahankan status quo; (5) konflik antarbanjar terkait dengan otonomi daerah; 
(6) konflik politik, konflik antar banjar, intern banjar yang sering muncul ke permukaan misalnya kasus-kasus kasepekang, katundung, atau pengadilan massa.

Mencermati potensi konflik yang ada, sudah seharusnya dilakukan upayaupaya pencegahan agar tidak bereskalasi lebih besar yang dapat merusak tatanan kehidupan sosial yang harmonis. Betapa pentingnya peran kepemimpinan desa pakraman sebagai pemimpin lokal bersinergi dengan kepemimpinan desa dinas dalan mempertahankan keharmonisan dan integrasi masyarakat. Bagi masyarakat Bali peran seperti ini relevan dengan ajaran catur guru. Salah satu catur guru bagi masyarakat desa pakraman di Bali adalah guru wisesa, yaitu pemerintah. Para prajuru desa pakraman dan desa dinas adalah unsur pemerintahan terkecil atau terendah dalam kehidupan masyarakat di Bali (Widja, 1994). Dari sisi kepentingan krama desa pakraman maupun dari perspektif para prajuru, kepemimipinan desa pakraman memiliki peranan penting bagi pembangunan masyarakat desa (Indriyati, 2005) termasuk menjaga keharmonisan dan integrasi masyrakat. Bagi krama desa pakraman, pemimpin desa itu adalah guru, sehingga para prajuru haruslah dihormati, disegani, dan dipatuhi. Sebaliknya, para prajuru desa pakraman sebagai guru tentu harus memiliki sifat-sifat ketedanan dan menjadi sumber informasi bagi krama. Relevan dengan penelitian Indriyati (2005) tentang Peran Kepemimipinan Kepala Desa terhadap Pendaftaran Tanah di Karangasem, Bali yang salah satu hasilnya menunjukkan bahwa faktor kepemimpinan kepala desa dapat meningkatkan pendaftaran tanah masyarakat dengan kontribusi sebesar $93,76 \%$. Selain faktor kepemimpinan, pelibatan agen sosial mempunyai peran penting dalam menjaga keharmonisan dan integrasi desa pakraman dan desa dinas. Pelibatan agen sosial di wilayah desa pakraman dianggap wajar mengingat setiap kelompok masyarakat memiliki agen sosial yang menurut Margi
(2011) karena mereka memiliki sumbersumber kekuasaan yang berpengaruh untuk mengatur kehidupan sosial bersama.

\section{SIMPULAN}

Desa dinas dan desa pakraman di Bali pada umumnya berada dalam kondisi harmonis dan terjadi hubungan komunikasi antara unsur desa dinas dan desa pakraman dalam susunan struktur pemerintahan. Keharmonisan desa dinas dan desa pakraman memunculkan ungkapan "satu badan dua kepala". Dalam hubungan desa pakraman dengan desa dinas perlu diwaspadai terhegemoninya desa pakraman oleh kekuasaan negara yang dipersonifikasi oleh desa dinas (kelurahan) sebagai perpanjangan tangan negara. Desa Pakraman sebagaimana tertuang dalam Perda No. 3 Tahun 2001 tentang Desa Pakraman mempunyai tugas dan kewenangan yang sangat penting dan strategis. Adapun tugas tersebut adalah: membuat awig-awig, mengatur krama desa, mengatur pengelolaan harta kekayaan desa, bersama-sama pemerintah melaksanakan pembangunan di segala bidang terutama bidang keagamaan, kebudayaan, dan kemasyarakatan; membina dan mengembangkan nilai-nilai budaya Bali dalam rangka memperkaya, melestarikan, dan mengembangkan kebudayaan nasional pada umumnya dan kebudayaan daerah pada khususnya, berdasarkan paras-paros, sagilik-saguluk, salunglung-sabayantaka (musyawarah mufakat), mengayomi krama desa. Sedangkan wewenang Desa Pakraman adalah: (a) menyelesaikan sengketa adat dan agama dalam lingkungan wilayahnya dengan tetap membina kerukunan dan toleransi antarkrama desa sesuai dengan awig-awig dan adat kebiasaan setempat; (b) turut serta menetukan setiap keputusan dalam pelaksanaan pembangunan yang ada di wilayahnya terutama yang berkaitan dengan Tri Hita Karana; (c) melakukan perbuatan hukum di dalam dan di luar desa adat. 
Desa sebagai pakraman kearifan lokal sampai saat ini masih lestari, yang dipergunakan sebagai pusat orientasi bagi orang Bali. Namun, pada aspek tertentu utamanya pengelolaan harta kekayaan desa mengalami pergeseran. Pergeseran yang dimaksud adalah bahwa pengelolaan harta kekayaan desa beberapa tahun yang lalu dikelola oleh pribadi dan untuk kepentingan pribadi, namun sekarang sudah dikelola oleh desa pakraman. Integrasi

masyarakat, multikulturalisme secara normatif tertuang dalam Peraturan Daerah No. 3 Tahun 2012 tentang Desa Pakraman dalam pasal 3 ayat (7): parahyangan dan tempat suci, baik bagi umat Hindu maupun umat lain yang ada dalam wilayah desa pakraman/banjar pakraman dijaga bersama-sama oleh seluruh warga/krama dari desa pakraman/banjar pakraman atas dasar toleransi dan kerukunan serta saling menghormati dalam rangka membina rasa persatuan dan kesatuan masyarakat Indonesia. Implementasi dari pasal 3 ayat 7 di atas di Desa Pakraman Kuta, terdapat hubungan secara sosio-historis dari aspek multikulturalisme sudah mulai ketika mads langa di Kuta yaitu ketika zaman kerajaan. Mads langa kawin dengan keturunan Tionghoa sehingga disebut mads langa adalah bagian dari kehidupan dan dinamika masyarakat Tionghoa di Desa Pakraman Kuta. Seperti dikemukakan oleh (Fay dalam Atmadja, 2004) dualisme dikotomik bisa mendorong terjadinya suatu pertentangan antara dua entitas dan kekuatan yang harus dipilih keberpihakannya, yakni pihak ini atau pihak itu. Bersamaan dengan itu, konflik yang semula bersifat perebutan sumber daya ekonomi maupun politik bisa berubah menjadi konflik antara kita dan mereka, muwed dan tamiu, atau Bali melawan etnik non-Bali. Upaya-upaya tersebut di atas relevan dengan pendapat Soerjono yang menyatakan bahwa ada tiga jenis pola penanganan kasus adat, yaitu : pola negosiasi, pola mediasi, dan pola ajudikasi.

\section{DAFTAR PUSTAKA}

Astara, Wesna I Wayan. 2010. Pertarungan Politik HukumNegara \& Politik Kebudayaan. Denpasar: Udayana University Press.

Atmadja, Bawa. N.1996. Ngusaba Ngelarung Bikul: Kearifan Tradisional dalam Menanggulangi Hama Tikus di Desa Adat Julah Tejakula Bali. Laporan Penelitian. Singaraja: STKIP Negeri Singaraja.

2004. Sumber Konflik pada Desa Adat Multietnik di Kabupaten Buleleng. Dalam Media Komunikasi FPIPS Vol.3.No.1 April 2004.

Carspecken, P.F. 1996. Critical Ethnograpyphy in Educational Research : A theoritical and practical guide. London and New York: Routledge.

Griadhi, I Ketut Wirta. 1991. Peranan Otonomi Desa Adat dalam Pembangunan. Kerta Patrika No. 54, Th. XVII. h. 57-62.

Indriyati. 2005. Peran Kepemimpinan Kepala Desa terhadap Pendaftaran Tanah di Kabupaten Karangasem Provinsi Bali. Laporan Penelitian. (Tidak Dipublikasikan). Jakarta: Puslitbang Badan Pertanahan Nasional.

Margi. I K. 2011. Pemertahanan Identitas Etnik dan Implikasinya terhadap Hubungan Intern dan Interetnik di Desa Pengastulan, Buleleng, Bali. Disertasi (Tidak Diterbitkan) Denpasar: Pascasarjana.

Miles M.B and Huberman, A.B. 1992. Analisis Data Kualitatif (Terj. Jakarta: UI Press.

Perda Provinsi Bali No.3 Tahun 2001. Tentang Desa Pakraman, Bali: Biro Hukum dan HAM Setda Bali. 
Pitana. I Gde. 2000. Cultural Tourism in Bali, a Critical Appreciation. Denpasar: Research Centre for Culture and Tourism, and Bali Post.

Suparlan, P. 2002. Menuju Masyarakat Indonesia Yang Multikultural (Makalah disampaikan pada Simposium Antropologi Indoneisa di Denpasar, Bali, 16-21 Juli 2002)
Undang-Undang No. 32 Tahun 2004 Tentang Pemerintahan Daerah, Jakarta: Sinar Grafika.

Widja. I G. 1994. Dualisme Kepemimpinan Lokal pada Desa-desa Pegunungan di Kabupaten Buleleng dan Implikasinya dalam Pembangunan. Laopran Penelitian. Singaraja: STKIP. 